\title{
Relation between students' involvement and teacher management strategies in French 'difficult' classrooms
}

\section{Olivier Vors \& Nathalie Gal-Petitfaux}

To cite this article: Olivier Vors \& Nathalie Gal-Petitfaux (2015) Relation between students' involvement and teacher management strategies in French 'difficult' classrooms, Physical Education and Sport Pedagogy, 20:6, 647-669, DOI: 10.1080/17408989.2014.882889

To link to this article: http://dx.doi.org/10.1080/17408989.2014.882889

\section{曲 Published online: 11 Feb 2014.}

\section{Submit your article to this journal $\longleftarrow$}

Џ Article views: 123

Q View related articles ¿

View Crossmark data〔 


\title{
Relation between students' involvement and teacher management strategies in French 'difficult' classrooms
}

\author{
Olivier Vors $^{\mathrm{a} *}$ and Nathalie Gal-Petitfaux ${ }^{\mathrm{b}}$ \\ ${ }^{a}$ University of Lille, FSSEP Lille 2, ER3S EA 4110, 9 rue de l'université, 59790 Ronchin, France; \\ ${ }^{b}$ University of Clermont-Ferrand, University Clermont Ferrand 2, STAPS, ACTé, Université \\ Blaise Pascal, BP 104, 63172 Aubière Cedex, France
}

(Received 19 October 2011; final version received 8 January 2014)

Background: Since 2010, French secondary schools with a high proportion of students in academic difficulty benefit from a compensatory education policy called 'Écoles Collèges et Lycées pour l'Ambition, l'Innovation et la Réussite' (ECLAIR). These students tend to behave poorly and frequently disengage from learning tasks, and thus one of the greatest challenges for teachers is to keep them focused and active. The 'academic learning time in physical education' is very low, about $14.4 \%$.

Purpose: This case study investigates the relations between the students' motor and social involvement and the class management strategies of four experienced physical education (PE) teachers in a difficult educational context.

Participants and Setting: This case study focuses on four secondary school classes with the same characteristics: all are part of the ÉCLAIR program, are taught by experienced $\mathrm{PE}$ teacher, with hardly manageable underachieving students in drop-out situations (16 in total, between 12 and 16 years old), and offer four units of gymnastics (for a total of 26 lessons). The classes were organized as group activities, with instruction sheets, with an educational project based on the students' sense of autonomy and responsibility. Research Design: This research was conducted following a situated approach from the cognitive anthropology framework of 'course of action'.

Data collection: Extrinsic classroom data were collected by observing the students' and teacher's activities within the classroom and using audiovisual recordings. Intrinsic data were collected during self-confrontation interviews held after the lessons.

Data Analysis: The data were processed in three stages: (a) the structure of students' and teachers' behaviors; (b) the dynamic of students' and teachers' experience, and (c) the classroom management strategies related to student misbehavior.

Findings: The findings reveal that in spite of permanent classroom agitation, working involvement predominated with only short periods of student disengagement. Compromises organize the relation between students' involvement and teacher management strategies. There is a compromise between work and play time for the students - they mainly remained involved in their work, and were appropriately involved in their task both physically and socially. Then, there is a compromise of acceptance for the teachers, as they use specific management strategies based on controlled short drop-outs as a source of student involvement in work.

Conclusions: These findings raise the question of how PE teachers working under the compensatory policy can best manage student misbehavior. The teacher's acceptance, compromises within the classroom, zone of acceptable responses, and articulation of instruction activity with misbehavior management, are as many factors improving teachers' professionalization.

\footnotetext{
*Corresponding author. Email: olivier.vors-2@univ-lille2.fr
} 
Keywords: physical education; classroom management strategies; misbehavior; compromises; acceptance

\section{Compensatory education policies}

In the late 1960s, many countries, including the USA, the UK, and France, developed compensatory education policies. Initially, these policies were based on the concept of 'cultural deprivation' and aimed at managing school disorder. In the USA, a policy of 'positive discrimination' has driven compensatory education since the 1960s, when President Lyndon B. Johnson declared 'War on Poverty.' Various programs were implemented under the Economic Opportunity Act of 1962 and the Elementary and Secondary Education Act: title 1 in 1965. The most famous of which are Head Start, Follow Through (for a review, see Ward and O'Sullivan 2006). In the UK, compensatory education is driven by the notion of policy areas, with a focus on 'disadvantaged areas,' and was updated by the Plowden Report (1967). The main programs have been the Education Priority Area (EPA) of the 1960s and Excellence in Cities in 1999 (Machin, McNally, and Meghir 2004). In France, the compensatory education policy lies between those of the USA and the UK and incorporates the notions of both policy areas and positive discrimination. However, as noted by Senac (2000), the emergence in 1981 of 'Zones d'Éducation Prioritaire $^{1}$ (ZEP) by Alain Savary ${ }^{2}$ is specific to France. According to Senac (2000), foreign experiences did not greatly influence French policy, as the major influences were the ideas of the General Trade Union of Education and Public Research (SGEN-CFDT) and the findings of French educational research. Several programs grew out of the original ZEP of 1981, and ZEP was replaced by a new policy of ÉCLAIR in 2010. This development reflects a shift in political concerns from an initial focus on helping disadvantaged students to the development of strategies to manage student misbehavior (Kherroubi and Rochex 2002; Millet 2004).

Most studies on these compensatory policies concentrate either on the students' behavior within the school or class, or on the teacher's management of the class. But they do not focus on the relations between the students' behavior and the class management strategies, nor on how does the teacher articulate the class management strategies with the teaching strategies. Researches on students' activity within schools parts of the compensatory policy are often quantitative (Kherroubi and Rochex 2002, 2004). Their goal was to evaluate their effectiveness by comparing changes in student performance as reflected by national tests in French and mathematics (Bénabou, Kramarz, and Prost 2009; Demeuse et al. 2008). Qualitative research is less common and tends to address misbehavior at school, with few studies focusing on the problems encountered by the teachers. The few studies in the classroom context particularly highlight the difficulty for the teachers to get and keep their students involved in the lesson (Armand and Gille 2006). In this context, building a sustainable working group of students is a challenge for teachers (Rouve and Ria 2008), and 'managing the class in acceptable conditions of communication in a specific location and for a certain time is not the starting point of the school situation but one of its objectives' (Kherroubi and Rochex 2004, 172). In these difficult contexts, teachers often feel their work is exhausting and frustrating, which leads them to find compromises so they can make it through their day's work (Rouve and Ria 2008). The challenge of class management is particularly difficult in PE;

the structure of a traditional academic classroom often gives students a private environment to complete work and confines social opportunities because students spend a majority of their 
time in desks. Teacher directed activities are also common in the traditional classroom setting. By comparison, PE classes are usually centered on physical abilities and often related to sport activities. This changes the dynamic from a teacher-student interaction to more of a studentstudent interaction. PE classes tend to be public in terms of peer groups and also performancebased, which amplifies the self-conscious changes that adolescents experience. (Garn, Ware, and Solmon 2011, 86)

\section{Classroom management and misbehavior in PE}

The studies of classroom situations with difficult students have been conducted from three research perspectives: behavioral, ecological, and situated action. They show that teachers manage these classes only with great difficulty due to frequent disengagement of the students.

Behavioral researchers were the first to look at the effectiveness of teaching practices in these difficult contexts. They found out that disturbing behaviors appear very frequently during PE lessons with one disciplinary incident every three to four minutes in secondary schools (Piéron and Emonts 1988), against one every two minutes in primary schools (Turcotte et al. 2008). These incidents are mostly not oral but physical deviances, moving about or off-task behaviors (Hardy, Hardy, and Thorpe 1994; Turcotte et al. 2008), conflicts between students (Piéron and Emonts 1988), or between teacher and students (BeckersLedent et al. 1995; Hardy 1999). The findings detect four basic categories of student behavior : (a) students involved with the 'task-as-stated-by-the-teacher;' (b) students involved in a 'modified-task;' (c) students involved in 'deviant off-task behavior;' and (d) students acting as 'competent bystanders' (to avoid participation without misbehaving) (Tousignant and Siedentop 1983, 49). These researches show that class management has two objectives: 'Here the goal has been to reduce off-task behaviour and increase on-task behaviour' (Ward 2006, 9). Moreover, the more difficult the situation is, the more time the teacher spends managing a multitude of off-task behaviors (Kounin 1970). The studies have shown two typical features of student behavior in these difficult classes, the first concerning actual practice time and the second, social behavior. First, the academic learning time in physical education (ALT-PE) for difficult students is particularly low: $14.4 \%$ of the total lesson time (Vors, Gal-Petitfaux, and Cizeron 2010) compared with $21.9 \%$ in the usual context (Piéron 1993). Various studies have shown that 'the more difficult students spend a quarter less time at practicing the activity during the lesson' (Piéron 1993, 57). These findings emphasize a parallel trend in the high rate of disengagement. Such students are unable to stay on task and permanently generate off-task behaviors. 'One of the strongest indicators of disengagement is physical withdrawal from schooling, which includes such behaviours as tardiness, cutting classes, chronic truancy and dropping-out' (Pellerin $2005,1159)$. Second, this type of study has emphasized social behavior as a main factor in student disengagement from school tasks. Social relationships are highly valued by students, particularly in PE and especially for difficult students: 'Establishing and maintaining meaningful relationships with peers is a critical social skill for students' (Ward 2006, 13). Others studies focus on the teachers' behavior. They analyze misbehaviors detected in case of a major incident with a multidimensional category system in which students and teachers are simultaneously coded (Brunelle et al. 1993; Hardy 1996; Piéron and Emonts 1988; Turcotte et al. 2008). In conclusion, behavioral researches are highly efficient to identify several behavior categories: students' off-task behaviors and teachers' management strategies. More generally, these categories allow an accurate description, essential when trying to understand what happens in PE classes. Behavioral research also studies the 
interactions between students' and teachers' interrelated behaviors within teaching contexts, combining data collected through observation (accessing behaviors and strategies), and through questionnaires and interviews (accessing what the participants think about the educational setting and their interpretation of events they have experienced) (Piéron 1982). However, two limits must be emphasized: the difficulty to build an interpretation of events experienced by the participants (Piéron 2005), and to explain how the actions are related to each other during a period of activity.

Ecological research is more focusing on the dynamic and interactions of the classroom (Doyle 1977). Social misbehaviors are not opposed to work behaviors but appear as components in classroom interactions. In the class, on-task and off-task behaviors are integrated into one complex system of interrelationship between managerial (maintaining order), instructional (promoting learning), and student social (socializing) systems (for a review in PE, Hastie and Siedentop 2006). The managerial system provides rules, routines, and expectations for students to allow learning to take place. The instructional system involves the presentation and practice of the subject matter. The social task system was first emphasized by Allen (1986), who described it as having two major goals, that of socializing and that of passing the course (Dyson, Linehan, and Hastie 2010, 115). Research from sports education and adventure education in PE has extended Allen's (1986) work to show that the social task system can actually enhance and not necessarily impede student learning (Carlson and Hastie 1997; Hastie 1995, 2000; Hastie and Siedentop 2006). Several studies have shown the problematic teacher-students relationships in difficult classrooms. The teachers' instructional activity is permanently thwarted, hindered, or interrupted by student transgressions (Hastie and Siedentop 2006). They are constrained to allow certain student social interactions and to informally accept certain misbehaviors provided that they do not interrupt the smooth running of the lesson (Hastie and Pickwell 1996). The more difficult the context, the more teachers develop a large 'zone of acceptable responses' and accept off-task behavior (Sanders and Graham 1995). On the other hand, the students' classroom activity is marked by numerous acts of disengagement in opposition to the teacher's expectations in order 'to reduce the demands of a task, to lessen the chances of being held accountable, to seek a more interesting task, to engage socially with peers, or even out of boredom' (Sanders and Graham 1995, 215). Within the 'system class,' teachers and students cooperate and reach 'trade-offs' out of necessity (Hastie and Pickwell 1996); yet in difficult classes, this occurs frequently and is not always easy to handle. Ecological research reports on classroom life as a dynamic system of interaction and seeks to understand the goals of the various actors. However, similar to behavioral research, these studies do not provide access to what drives the actors to act in a given situation; that is, the reason behind their actions during interactions.

Another field of research based on the situated approach of the teachers' and students' activities within the class (Monnier and Amade-Escot 2009) brings another way of analyzing the classroom interaction given by the ecological perspective. This research is interesting in the sense that teachers assign to their interactions with students. The findings have shown that in difficult classes, teachers' and students' activities are both impeded: their concerns compete (Monnier and Amade-Escot 2009). This approach shows that the concerns and actions of teachers and students are co-constructed. To explain these phenomena of coordination in the classroom, the researchers rely on the subjective perspective of actors through interviews. They provide insight into what drives teachers and students to act in the classroom. The teacher hinders the activity of difficult students and prevents them from socializing as they want. The analysis of the action suggests that students often do not understand why this is happening and they develop a strong sense of frustration and injustice that 
leads them into conflict with the teacher (Flavier et al. 2002). For their part, the students' actions upset the teacher's activity. By their continual transgressions, they hinder the teacher's instruction activity (Monnier and Amade-Escot 2009). Durand (1996) showed that managing classroom order is a primary concern for teachers, even more important than student involvement in learning tasks. During open conflict with students, teachers must interrupt the flow of the lesson to manage misbehavior (Flavier et al. 2002). In PE classes, teachers may feel divided between conflicting concerns 'relative to the management of the lesson syllabus along with the students' lack of discipline' (Flavier et al. 2002, 29). The teachers experience these classroom situations as particularly unstable; they are exhausted by the permanent need to try to coordinate their actions with those of students. A few studies have shown that experienced teachers (Chauveau 2001) manage to create an atmosphere of involvement in the classroom, maintain it, and coordinate their apparently incompatible concerns with those of the students (Gal-Petitfaux and Vors 2008). Thus, a situated approach shows the concerns and actions of the actors linked with a definite situation. Only a few situated approaches focus on the strategies adopted by the teachers to coordinate their activity of instruction and maintaining order with the students' misbehaviors.

\section{Purpose}

Only a few studies have focused on the relationship between teacher and students, or on the dynamic of activity of actors' in the context of difficult classes operating under compensatory education policies. This case study investigates the relations between the dynamics of the students' motor and social involvement and the teachers' classroom management strategies, in a difficult specific educational context. More particularly, in this specific context, we sought to analyze the activity of teachers and students in order to understand how teachers interact with students to manage their misbehavior and to maintain a positive dynamic of students' involvement.

\section{Theoretical framework: course of action}

This study is part of an approach to the activity of actors in the context described as the 'situated approach' (for a review in PE, Rovegno 2006) and makes use of a theory based on the principles of situated action and situated cognition: the semiotic framework of the 'course of action' (Theureau 2003, 2006, 2009; Theureau and Filippi 2000). This theory was inspired by situated cognitive anthropology (Durand 1996; Gal-Petitfaux et al. 2010) and has provided the basis for a considerable amount of French research in various fields related to sports practices over the past 10 years, including collective activity in high-level sports (Bourbousson et al. 2011); coaches' and elite athletes' activities (Hauw, Renault, and Durand 2008; Sève et al. 2005); student activity in sports (Guillou and Durny 2008); activity configurations, interactions, and cognitive artifacts (Veyrunes, Gal-Petitfaux, and Durand 2009); novice teachers and physical education teacher education programs (Ria et al. 2003); experience and professional knowledge construction (Flavier et al. 2002; Méard, Bertone, and Flavier 2008); and pedagogical supervision and pre-service/mentor interactions (Chaliès et al. 2010).

Our work lays on the theories of situated action (Suchman 1987, 2007) and distributed cognition (Hutchins 1995; Lave 1988) following the assumption that an action is physically, temporally, spatially, and socially situated. This assumption is added to the hypothesis of the 'course of action,' which emphasizes the temporal dynamics of activity, the actor's subjectivity, and the collective activity (Theureau 2003, 2006, 2009). Within this framework, the interactions between actors and their environment are considered as unbalanced in the 
sense that actors select only those things in the environment that are relevant at a given moment to their internal organization. For the course-of-action theory, the level of action that is meaningful for an agent is the level that can be shown, told, and commented on. This theory is based on the assumptions that the level of experience that is significant from the actor's standpoint is a level of organization relatively independent of other possible levels of activity analysis and that it may give rise to valid and useful observations, descriptions, and explanations.

Thus, the course of action theory posits that by gaining access to the temporal dynamics of meaning constructed by the actors during their activity, one can account for their interactions with the environment and explain how they build themselves in a given context. In the case of teachers, such access should help to better understand how they act and interact in the classroom. With this approach, activity is regarded as a course of experience composed of subjective concerns, perceptions, and knowledge permanently changing over time. This experience is described as an individual-social activity; that is, as the experience of how other people are part of the actor's pre-reflexive consciousness in the course of his interactions (Theureau 2006).

\section{Methods}

\section{Participants and settings}

The specific context of this research includes common characteristics to all studied classes:

- The secondary schools chosen are ranked as a top priority in the ÉCLAIR program for French compensatory policy (i.e. belonging to the most troubled schools in France). These schools were identified according to the students' daily demonstrations of major incivilities.

- The four selected classes (one per secondary school) were mixed-sex. There were considered by the teaching staff as particularly difficult because of student unrest and misbehavior. On average, each class included 17-24 students.

- The four PE teachers (two women and two men) are experienced (Chauveau 2001), they agreed to partner with the study after being briefed on the research topic and protocol.

- Sixteen students (four per class) between 12 and 16 years old (seven girls and nine boys) were selected by the teachers as presenting the strongest behavioral issues. They are underachieving students in drop-out situations. To preserve anonymity, the participants' names have been changed (Figure 1).

- The chosen PE lessons were gymnastics workshops comprising six or seven lessons each (i.e. 26 lessons in total). During these lessons, the gymnastics workshops were organized in parallel. Students should work in groups of three to five people and learn several motor skills at each workshop. The spatial organization clearly shows the definite location of each activity. For all of them, the students were given an instruction card on which the teacher specified the working conditions (working abilities, repetitions, and criteria to self-evaluate their successes and failures).

- Each school's PE educational project states that the objective of these gymnastics activities is to develop the sense of autonomy and responsibility of the students.

The four teachers chose that type of work plan to improve the students' sense of autonomy; but it offers them many opportunities to behave poorly as they often work without 


\section{Kevin}

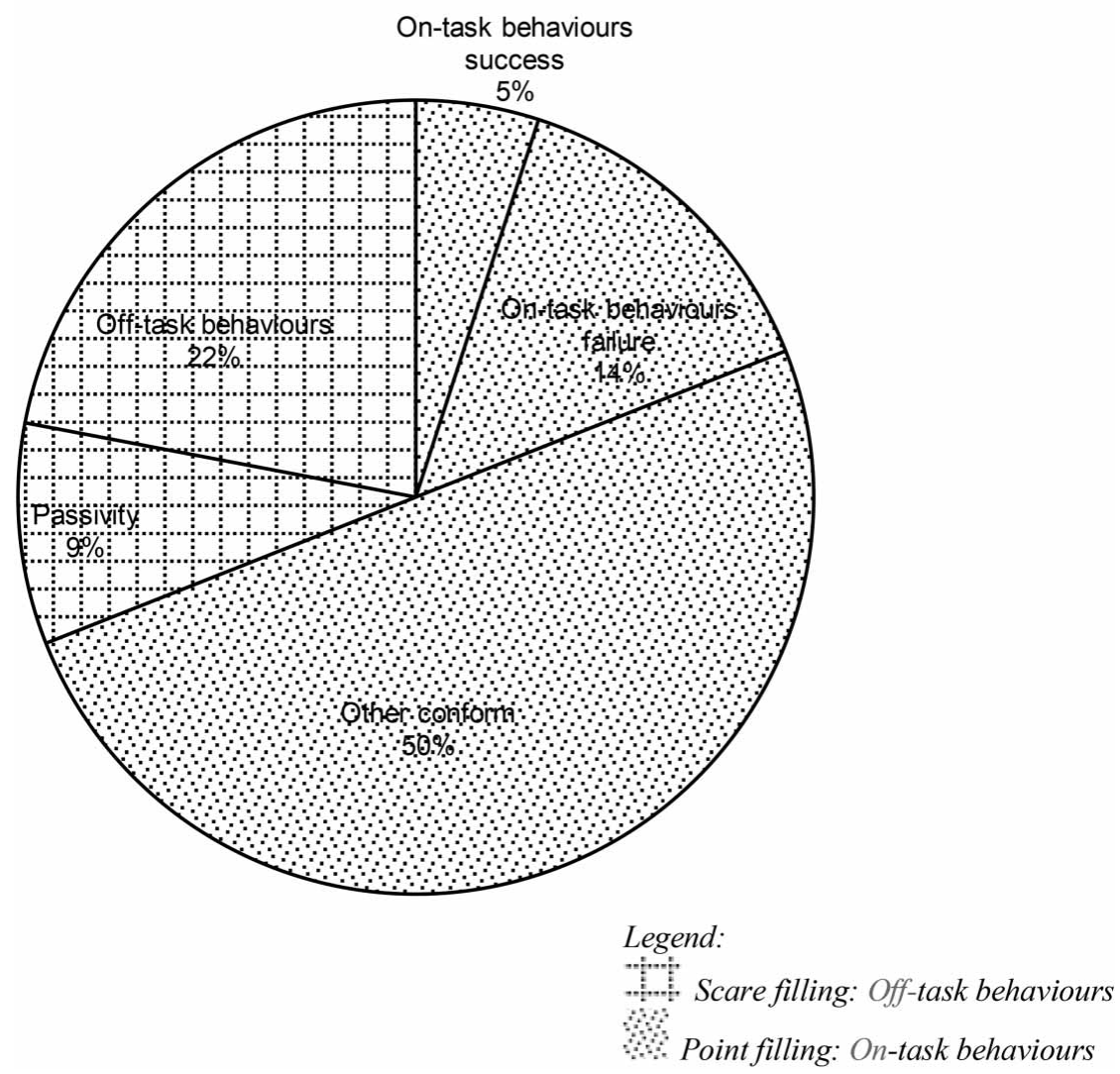

Figure 1. Example of categorization of Kevin's behavior in lesson 1 and distribution (in \%) of the time involvement in each category.

teacher management. Moreover, the presence of numerous and various items (e.g. gym mats, trampolines) is another reason for the students to play and be distracted from their task. For the teacher, this work plan brings difficulties to manage the class - as they have to manage several groups simultaneously, spread over a vast environment, and cannot supervise all students at the same time. Thus, this particular context, including difficult students working by themselves in small groups, is seen as prime situation to study the students' involvement and classroom management.

\section{Data collection}

As explained above, two types of data were collected: extrinsic and intrinsic. The extrinsic data were collected in class from ethnographic notes and audiovisual recordings. The recorded data were collected by a video camera and a wireless microphone worn by the teacher. These data were used to identify traces of the classroom activity dynamic of teachers and students and their interactions.

The intrinsic data were collected from individual self-confrontation interviews held after the lessons in the gym by the researcher (Theureau 2010). All four teachers and 16 
students were invited to take part in interviews. They were to face their own image issued from the audio and video recordings of the lessons using a computer with pinnacle studio software (Table 1). Each actor went through two interviews (in total, 8 teacher interviews and 32 student interviews). They were asked to comment on their practical actions, communications, interpretations, feelings, and focus during the recorded activity. Either party could stop the tape or backtrack at any time to facilitate descriptions and comments. The researcher's prompts were concerned with eliciting descriptions of the actions and events as experienced by the actor; requests for interpretations and generalizations were avoided. The prompts were designed to focus the students' attention on the dynamic of their involvement (i.e. the elements in the situation inciting them to focus or withdraw) and the teachers' attention on interactions with misbehaving students during the lesson (i.e. events where student misbehaviors made sense to them), encourage them to be more specific, and obtain additional information.

This study was based on collaboration with the participants of the study agreeing on the conditions of participation, the objectives of the study, the use of the image, and data protection. First, to avoid the potential bias that a video recording could have on the students' and teachers' behaviors, the protocol was built gradually. We had to gradually get both teachers and students used to work in a classroom with recording material. The video camera was installed three lessons before the beginning of the study. We attempted to be as unobtrusive as we could by positioning the camera in a corner of the gymnasium and by being as discreet as possible. Second, we progressively built a relationship with the participants during maintenance sessions - we established a relationship based on mutual trust so that they understand they would not be evaluated nor judged. We also explained that the audio and video recordings were merely there to help understanding their actions and feelings within the classroom.

\section{Data analysis}

The data were processed in three stages. We identified: (a) the structure of students' and teachers' behaviors; (b) the dynamic of students' and teachers' experience, and (c) the classroom management strategies related to student misbehavior.

\section{The structure of students' and teachers' behaviors}

The extrinsic data were analyzed qualitatively and quantitatively to identify the structure of students' and teachers' behaviors. We established a summary analysis of the numerous

Table 1. Participants of the study.

\begin{tabular}{lll}
\hline & Students & Teachers \\
\hline $\begin{array}{l}\text { Secondary school 1 } \\
\text { Cycle of six lessons audio-video recorded }\end{array}$ & $\begin{array}{l}\text { Girls: Nawel, Pauline } \\
\text { Self-confrontation interviews on lessons 4 and 5 }\end{array}$ & Mrs D \\
$\begin{array}{l}\text { Secondary school 2 } \\
\text { Cycle of seven lessons audio-video recorded }\end{array}$ & $\begin{array}{l}\text { Girl: Yasmine } \\
\text { Boys: Kévin, Rachid, Sourak }\end{array}$ & Mr X \\
$\begin{array}{l}\text { Self-confrontation interviews on lessons 1 and 5 } \\
\begin{array}{l}\text { Secondary school 3 } \\
\quad \text { Cycle of seven lessons audio-video recorded } \\
\text { Self-confrontation interviews on lessons 3 and 4 }\end{array}\end{array}$ & $\begin{array}{l}\text { Girls: Léa, Megda } \\
\text { Boys: Mohamed, Nordine }\end{array}$ & Mrs Y \\
$\begin{array}{l}\text { Secondary school 4 } \\
\begin{array}{l}\text { Cycle of six lessons audio-video recorded } \\
\text { Self-confrontation interviews on lessons 2 and 4 }\end{array}\end{array}$ & $\begin{array}{l}\text { Girls: Alice, Soumaya } \\
\text { Boys: Benjamin, Tony }\end{array}$ & Mr W \\
\hline
\end{tabular}


extrinsic data collected (ethnographic notes, and audio and video recordings). At first, the extrinsic data were processed qualitatively. The various behaviors were coded and described through audio and video recordings. These descriptions were chronological, following the development of the lesson in order to highlight the dynamics of the various behaviors.

Second, a quantitative analysis of the extrinsic data in agreement to the ALT-PE method (Berliner 1979; Siedentop 1983; Siedentop, Tousignant, and Parker 1982; Van der Mars 2006) was added to complete this qualitative analysis (Table 2). Thus, the behavioral pattern of the different actors during lessons and their on-task time were identified. The interval recording instrument was slightly modified to be adapted to the specific group working situation in gymnastics (Gal-Petitfaux and Cizeron 2005): the coding categories were revised (Table 2) and the time interval was set at 10 seconds; the coding was done according to the progression of the lesson. In summary, using the video, we encoded the behavior: (a) the type of behavior according to ALT-PE categories; and (b) the duration of each behaviors category (the coded behavior being what was identifying the most representative category of the 10 seconds time interval).

Then the quantitative analysis was to calculate the distribution (in percentage) of the actors' involvement time in each category. Thus, the behaviors of the actors were presented in profile of behavior (an example of student profile on Figure 1).

The analysis of extrinsic data allowed to highlight the structure of classroom behavior. This extrinsic analysis was completed by an intrinsic analysis in order to understand the origin of these behaviors.

Table 2. Categories of behavior coding based on the ALT-PE instrument.

\begin{tabular}{|c|c|c|c|}
\hline \multirow[t]{6}{*}{$\begin{array}{l}\text { Teacher } \\
\text { behaviors }\end{array}$} & \multirow[t]{2}{*}{$\begin{array}{l}\text { Position of teachers with the students } \\
\text { observed }\end{array}$} & $\begin{array}{l}\text { Close to the student (in the space of his } \\
\text { workgroup) }\end{array}$ & I \\
\hline & & $\begin{array}{l}\text { Teacher away from students (outside of } \\
\text { his workgroup) }\end{array}$ & $\mathrm{O}$ \\
\hline & \multirow[t]{4}{*}{ Speaker who addressed the teacher } & The whole class & $\mathrm{CL}$ \\
\hline & & A group of students & GR \\
\hline & & Student observed & $\mathrm{SC}$ \\
\hline & & $\begin{array}{l}\text { A different student from the student } \\
\text { observed }\end{array}$ & S \\
\hline \multirow[t]{8}{*}{$\begin{array}{l}\text { Student } \\
\text { behaviors }\end{array}$} & \multirow[t]{2}{*}{$\begin{array}{l}\text { The student is involved in the motor } \\
\text { task required by the teacher }\end{array}$} & $\begin{array}{l}\text { The motor activity of the student is } \\
\text { appropriate }\end{array}$ & $\mathrm{MOa}$ \\
\hline & & $\begin{array}{l}\text { The motor activity of the student is } \\
\text { inappropriate }\end{array}$ & MOi \\
\hline & \multirow[t]{4}{*}{$\begin{array}{l}\text { The student is involved in a task } \\
\text { accompanying the motor task } \\
\text { required by the teacher }\end{array}$} & $\begin{array}{l}\text { The student has a cognitive activity } \\
\text { such as thinking, observing, listening } \\
\text { carefully to the teacher, completing a } \\
\text { worksheet (ONc) }\end{array}$ & \multirow[t]{4}{*}{$\mathrm{ON}$} \\
\hline & & $\begin{array}{l}\text { The student has a social activity to } \\
\text { advise or assist another student } \\
\text { (ONs) }\end{array}$ & \\
\hline & & $\begin{array}{l}\text { The student puts up and manages the } \\
\text { equipment (ONm) }\end{array}$ & \\
\hline & & $\begin{array}{l}\text { The student waits his turn to pass by } \\
\text { staying focused (ONw) }\end{array}$ & \\
\hline & \multirow[t]{2}{*}{$\begin{array}{l}\text { The student is not involved in a task } \\
\text { required by the teacher }\end{array}$} & $\begin{array}{l}\text { The student waits passively, without } \\
\text { disturbing the lesson (OFFw) }\end{array}$ & \multirow[t]{2}{*}{ OFF } \\
\hline & & $\begin{array}{l}\text { The student involved in a physically } \\
\text { deviant task (OFFt) }\end{array}$ & \\
\hline
\end{tabular}


The dynamic of students' and teachers' experience: Concerns, Interpretant, and Representamen

According to a postulate of the theory of the 'course of action' (Theureau 2006), each actor's experience is composed of various signs. To understand the origin of students' experience and teachers' management strategies, we analyzed the meaning constructed by the actors during their activity focusing on these aspects: his/her Concern, his/her Interpretant, and his/her Representamen. In each lesson, we identified student's and teacher's signs from their own experience they shared during self-confrontation interviews. The concerns are the major interests involving the actor in the situation - in this case, what are the student's motivations when they drop-out and what the teacher mobilizes when he manages misbehaviors. These concerns are identified by asking to each actor the following question about the collected and transcribed data: what are the main concerns for the actor at a given time, and what do trigger these reactions in this situation?

The Interpretant deals with the knowledge that the actor mobilizes at a given moment. It is constitutive of the actor's culture and prior experience mobilized at a given time, in relation to his/her concerns. Teacher and student Interpretant was identified with the following question: what practical knowledge is being constructed, validated, or invalidated by the actor at the given moment - during classroom management or during a student drop-out, for example?

The Representamen is the element which is significant to the actor at the chosen moment. It can be proprioceptive, perceptive, or mnemonic. The Representamen was identified using the following question: what element is significant to teacher and student in the situation? They were labeled with a sentence starting with 'I am perceiving ...' or 'I am remembering ...,' followed by a complement which was reproducing the comments of the actor when possible. By comparing these data of each actor, we are able to find out the recurring Concerns, Interpretant, and Representamen among students and teachers.

\section{Classroom management strategies related to student misbehavior}

This last step allowed us to demonstrate, in three stages, the typical character of teachers' misbehavior management during PE lessons. First, the students' misbehaviors and the teacher's classroom management strategies were analyzed crossing extrinsic data relating to the behaviors description and the intrinsic data relating to the experiences (Concerns, Interpretant, and Representamen). Second, the dynamic of interaction between students' misbehaviors and teacher management strategies was identified by paralleling them during the same period. Third, the typical relation between students' misbehavior and teacher management strategies was identified focusing on common features of the second stage.

\section{Data validity and agreement rate}

The data validity was obtained by triangulation. The agreement rate was obtained by the coding of two different researchers. They compared the coding of each action and communication between teacher and students one by one with the three components of the actors' experience. They systematically obtained an agreement rate higher than $83 \%$ at the end of each step. Sources of disagreement were discussed by the researchers until they reached an agreement close to $100 \%$. 


\section{Findings}

The findings pointed out that all four classes were involved in relatively studious activity during lessons. Teachers rarely had to interrupt a lesson on the long term to bring back discipline within the classroom. However, the students' work was marked by numerous disinvolvements and off-task behaviors. Two typical findings common to all actors showed that: (a) students' activity was mainly turned towards work based on a compromise between work and play time, due to (b) classroom management strategies based on a compromise of acceptance.

\section{Typical structure of students' involvement: a substantial learning activity despite permanent withdrawals}

The results showed that the dynamic of students' activity had a typical structure: the 'difficult' students are mainly involved in work in spite of permanent short withdrawals. This typical structure of students' involvement will be evidenced in two stages - first by presenting the structure of students' behaviors (with an analysis of extrinsic data based on video analysis and ALT-PE), and then with the dynamic of the students' concerns (by analyzing the intrinsic data of the self-confrontation interviews). However, to illustrate them, we will use some concrete examples that were chosen because they are emblematic of what all the actors do.

Structure of students' behaviors: a typical form of student disengagement non-prejudicial to work

The qualitative and quantitative analyses of the extrinsic data showed a typical structure of students' behaviors changing from frequent and ephemeral disengagement to long-time involvement in the task requested by the teacher. Several behaviors differ from what is expected by the teacher. These deviant behaviors generate a sensation of restlessness, typical to the studied classes. The amount of these behaviors (more than 40 different types were identified) produced during a short ${ }^{3}$ amount of time is high: the students are always moving about, exercising then discussing, suddenly leaving their task to go, talk to another student in a nearby group, etc. However, the organization of their behaviors and the common activity within the class are not chaotic.

Moreover, a detailed analysis of these extrinsic data showed a typical structure of students' behaviors dynamics. The course of behavior analysis showed cyclic organization alternating routinely between long consistent behavior and short deviant behavior. Moreover, the ALT-PE method highlights that hard-working behaviors expected by the teacher are dominant for 15 out of the 16 students during all four gymnastics cycles. The following example is representative of what happens for the 16 students studied in all four classes during all 26 lessons (Figure 2).

During this lesson, the four students produced a broad spectrum of behaviors (Figure 2) divided into the five categories presented earlier. The ALT-PE method added to the qualitative description of behaviors shows that all categories were composed by many types of behaviors. For example, when the students were involved in a task accompanying the motor task (coded as 'Other conform:' 59\% for Yasmine, 50\% for Sourak, 29\% for Rachid, 50\% for Kevin), this was manifested in different ways, such as when students were getting ready to go, waiting for their turn to go through, replacing or setting up equipment, talking to the teacher, helping a friend, or filling in the exercise sheet. Moreover, the specificity of the 
Yasmine
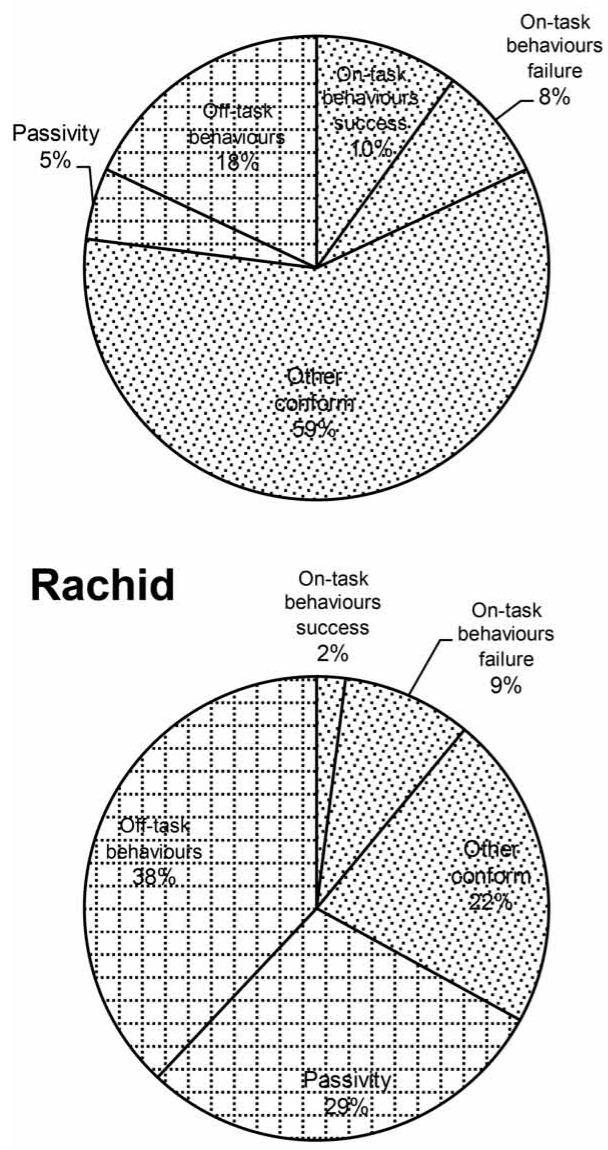

\section{Sourak}
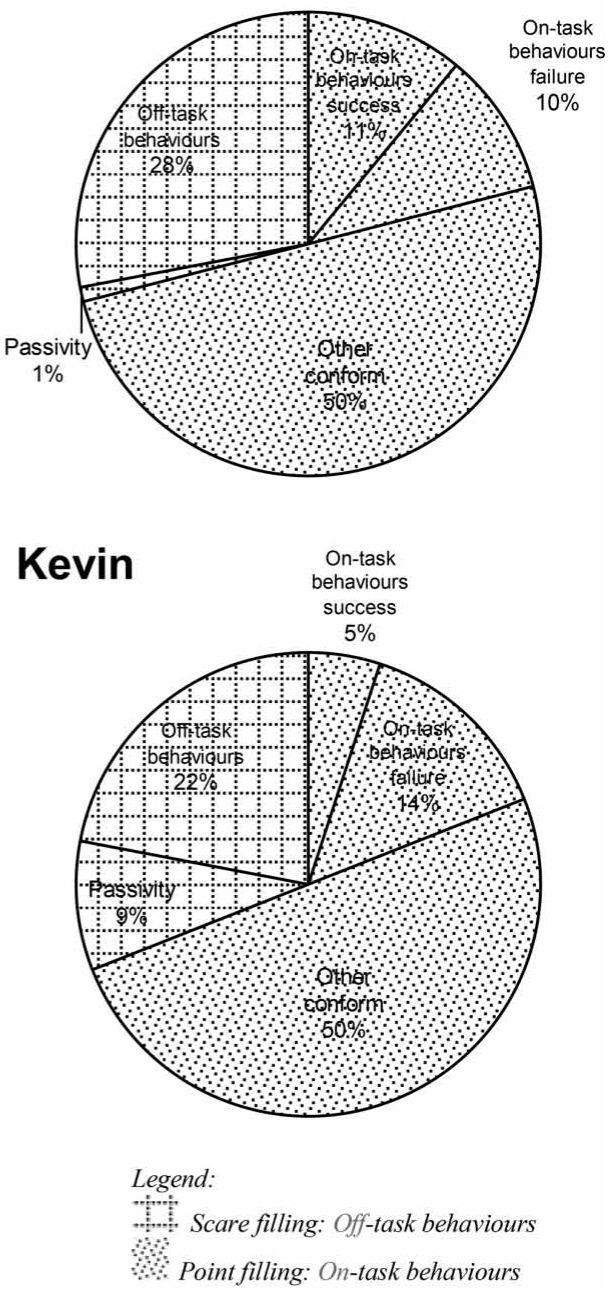

Figure 2. Students' typical behavior during the third lesson of teacher X.

students' course of behavior is that their misbehaviors have a very short duration. The dynamics of student involvement had a stable organization marked by a succession of sequences lasting no more than two successive occurrences. The students never stayed long on one activity: they changed permanently. For example, in one minute Sourak made a correct jump, put up the equipment, chatted with friends, gave a kick to a mat, made another jump, wandered around, waited idly, did some off-task behavior, read the exercise sheet, and called to the teacher.

The duration of off-task behaviors was rarely for more than one minute. Even when a student withdrew from the prescribed task, it was a minor event. All misbehaviors coded as 'Motor off-task' added to 'Passivity' (23\% for Yasmine; 29\% for Sourak, and 31\% for Kevin) were less prevalent than the task-oriented behaviors, except for Rachid (67\%). On average, they represented one-third of class time. Moreover, these off-task behaviors 
were characterized by furtiveness: although they were frequent, they remained low compared to on-task behaviors. The students performed one or two off-task actions that are not so 'severe' and then went back to be required work. This behavior shows that they were still involved in the given task with an appropriate motor and social involvement except during very short breaks. There was no sustained disengagement. Even when students were passive or apathetic (coded 'Passivity:' 5\% for Yasmine, 1\% for Sourak, 29\% for Rachid, and $9 \%$ for Kevin), this did not exceed three successive occurrences. On average, these passive behaviors represented $11 \%$ of the coded behaviors. They occurred when students doubled up while standing in line, were lying on the mats, or began wandering about the gym in search of an opportunity for change. Although physically inactive, the students scanned their environment looking for opportunities to escape boredom. Involvement in work and an appropriate motor involvement nevertheless remained dominant over off-task behaviors.

Behaviors consistent with the teacher's requirements were mostly present in $93.8 \%$ of the time ( 15 out of 16 students). They represented approximately two-thirds of their actions (average 62.5\%). These were the moments when the students were involved in carrying out the motor task; that is, the required gymnastics exercises of somersault and jump. In addition, the students periodically looked at the exercise sheet on which the exercises were explained. They also watched what others were doing to succeed. This type of behavior reflects their ability to work with relative autonomy and shows the efficiency of the teacher to deal with behavior management.

In summary, the qualitative analysis of audiovisual data showed a broad spectrum of behaviors, and identifying the course of behaviors composed of repetition and alternating of on-task and short off-task behaviors. The quantitative analysis of extrinsic data pointed out the dominance of on-task behaviors. Thus, both analyses combined showed a typical structure of students' behaviors. Students' behaviors are continually changing and off-task behaviors are continuously present and ephemeral throughout a period of activity. As a result, off-task behaviors do not disrupt on-task behaviors which have a longer duration. As it will be explained in the next section, the interviews with the students helped to understand what incites them to act in such a way and the dynamic that builds their course of actions during the lesson.

\section{Dynamic of the students' experience: compromise between work and play time}

Studying the course of action of the students brings the analysis one step further by highlighting the concerns beyond these behaviors. The findings show two typical concerns organizing the students' activity. One turned towards recreational activities, the other towards work activities. First, the idea of 'having fun provoking their peers by playing them nasty tricks' is permanently expressed through off-task activities. For example, this concern appears when they push another student during a somersault to make them fall, so they can have a laugh with their friends.

Kévin talks during the self-confrontation interview $\mathrm{n}^{\circ} 2$ : Yeah, here I'm having a bit of fun with my mate ... (laughs), he's going for a roll and boom ... I push him. He fell over ... We have a laugh together, he did it to me earlier... We're just having fun ...

Then, the concern of 'practicing the exercise' is materialized through behaviors corresponding to the teacher's expectations. For instance, this is the students' concern when they read the instruction sheet to understand what they have to do or look for advice. 
Nordine talks during the self-confrontation interview $\mathrm{n}^{\circ} 1$ : Here, I arrive at the activity, quickly read the sheet ... to go through the various exercises ... Here, I want to check if the exercises are hard (he executes them one by one, slowly and precisely). [ . . . Well, I try my best and then I practice this somersault, the hardest!

Both these concerns alternatively structure the dynamic of the students' activity, but training for the exercise overcomes ( $60 \%$ of the coded occurrences). The course of action analysis indicates that the students shift frequently from one of these concerns to the other in a circular way. For the students, being involved in the task set up by the teacher on the long term is related to the fact that they can alternate between entertaining and work activities.

\begin{abstract}
Nawel clearly expresses it during the self-confrontation interview $\mathrm{n}^{\circ} 2$ : Fortunately I can have a bit of fun now and again; otherwise it would be boring... I wouldn't even come to class anymore. [...] I work a bit but in the end it's boring to do the same thing over and over again, so I have a laugh with my mates ... It's no big deal, and after that I work as well.
\end{abstract}

Their major concerns are to find the best compromise between 'having fun' to avoid boredom, and respecting the instructions given by the teacher to avoid trouble. The sharp analysis of the students' course of action determines the knowledge required to adapt their behavior.

Within the interaction, they have developed three knowledge that organize their actions in order to 'avoid any trouble' with the teacher. First, the students have learnt how to hide their games from the teacher - by regularly checking the teacher's location in the classroom, being discreet not to be caught and staying within the space of their activity. Second, they know that the teacher will be more lenient if he sees them working several times, repeatedly and thus regularly all along the lesson. Third, they know they must adapt their actions in relation to what they think to be the teacher's state of mind. Thus, the dynamic of the students' activity is the result of a compromise between two contradictory concerns, work, and entertainment. Even if the students regularly withdraw from their task, these withdrawals are short and the students' concern rapidly turns to work. Analyzing the interviews shows that for most students, the most important factor for them to re-focus on their task (turning to a work concern) is when they perceive the presence (oral or physical) of their teacher.

For example, Tony, a particularly difficult student, talks during the self-confrontation interview $\mathrm{n}^{\circ} 2$ : 'If the teacher wasn't there, we'd just have fun all day. It's cool; we're winding each other up with my mates, making jokes (laughs). [ ... ] we've got to be sly not to get caught by the teacher.'

Finally, the analysis of students' self-confrontation interview shows that the major portion of time devoted to work is partly due to the teacher's management of misbehavior in the class. We can then study the teachers' activity to understand how they manage the students' misbehaviors, and how they can coordinate their activities of managing the class and teaching the students.

\title{
Classroom management strategies based on a compromise of acceptance
}

Although the classes were considered by the teaching staff as 'difficult,' the lessons went smoothly and without major clashes with these experienced teachers. To get these difficult students involved and keep them focused on their task during the whole lesson, the latter 
use particular strategies based on a compromise of acceptance. The findings common to all four teachers highlight two typical strategies: accepting some drop-outs and defining reaction boundaries.

Classroom management strategy: acceptance of short drop-outs as a source of student involvement in work

For the teachers, the findings show a typical management strategy consisting of accepting some minor deviances. This typical strategy will be presented among three steps: the typical aspect of acceptance of short drop-outs as a source of student involvement in work; the cause, based on teacher compromises; and the consequences on the smooth running of the course.

Description of the management strategy. The management strategy relies on the acceptance of short drop-outs that we identified earlier as a source of student involvement in work. The extrinsic data analysis of all teachers' behaviors allows understanding what happens during the PE lesson. The analysis of intrinsic data allows describing the primary concerns of the four teachers. Despite continuous deviances within the class, the teacher seldom intervenes repressively and most of his interventions aim at reminding the students what they have to do or helping them doing it. So, the main teachers' concern would be to obtain a working group activity in class. In fact, the main part of their interventions focuses on the expected motor and social abilities. The low frequency of these calls to order could look like too much permissiveness from the teachers. And yet, analyzing the interviews shows that the latter are perfectly aware of the students' continuous misbehaviors, and that they deliberately adopt a strategy to face it while maintaining a working atmosphere favorable to learning. This strategy of adapting to the nature of the perceived disturbances is based on the controlled acceptance of some minor deviances.

Causes of the management strategy. The findings pointed out the explanation of this management strategy based on the acceptance of some minor misbehavior. A thorough analysis of the teachers' experience, based on self-confrontation interviews, reveals that this strategy results from three types of compromises from the teacher: (a) the seeking for personal wellbeing, (b) the trust they have in their students, and (c) the necessity to keep them involved in their task. The results presented seem to be typical, i.e. recurrent in all the teachers studied. However, to illustrate this, in each part some quotes that represent very well the discourse of all subjects will be selected.

First, the first compromise is linked with the teachers' well-being. Teachers accept certain deviances they see as minor to avoid using all their energy on the withdrawing students at every instant. The following verbatim extract shows a singular example of this typical compromise of teachers' well-being.

Teacher X. talks during the self-confrontation interview $\mathrm{n}^{\circ} 2$ : If I could control all these disturbances, I would, but I can't, there is too much to do ... I would spend my whole time doing it ... the atmosphere would be tensed in the class, focused on disturbances. My job is not to be all about discipline, so I try to keep them focused on their work.

Teacher has constructed the practical knowledge that he must verify the ongoing of his repressive interventions. Before taking action, he tries to guess how long it will take for pointing out their poor behavior to students is not enough - he needs to check that they respect his remarks on the long term. He must then dedicate some time to follow 
his interventions - and the more interventions, the harder will it be to follow them and the more he might lose face with his pupils. Furthermore, each repressive intervention with students might be a source of conflicts that will have a deal with and that might disturb the progression of the lesson. This way, experienced teachers favor the smooth progression of the lesson trying to avoid conflicts. They express that not to intervene and focus on the work to be done is a source of frustration but that it is a necessary compromise in these classes.

Second, they also accept some disturbing behaviors because they know their pupils. The teachers have learnt to identify and accept some 'benign' dropping-out; they know it would not weaken the collective activity of the working class. Paradoxically, off-task behaviors are considered necessary for the collective work.

Teacher D. talks during the self-confrontation interview $n^{\circ} 2$ : Ultimately it’s almost better (misbehaviour) that they do this, instead of nothing, at least they're moving, at least they're active, so for me if they have a little fun for 30 seconds, then they will get back to work. It's their safety valve.

He has developed the empathic ability to put himself in their position and understand the reasons behind their actions. He knows that students having fun from time to time does not mean they will not go back to work, he knows that the students' dynamic of involvement in their work goes both through working and playing periods. When he detects a disturbance, he does not intervene straight away but controls the duration of the incidents. Most of the time, the problem solves by itself and it is not necessary for him to step in.

Third, he accepts some disturbances to keep the students involved in their task.

They assumed that these short games allowed longer-term involvement.

Teacher Y. talks during the self-confrontation interview $n^{\circ} 1$ : Here, I pretend not to have seen Marcel (who dived on the carpet) ... if not, you never stop (to interrupt the flow of the lesson). If you're all about order and discipline, these (particularly difficult) students drop out ... that doesn't work ... So you have lost everything: You have to manage conflicts in front of everyone or you have to manage truancy ... you know there are plenty (of students) who have completely dropped out and do not come to school anymore! (...) So there with Marcel, he dived, it's no big deal ... it allows him to breathe a little ... you see (the teacher shows the recording), he then returns (to work) by himself.

Finally, this strategy of accepting some misbehavior is experienced by all teachers as an addition of compromises, necessary to the smooth running of the lesson.

Consequences of this management strategy of acceptance. This management strategy of accepting some minor misbehavior has a direct effect on the classroom interactions and students' involvement. The teacher's management strategy allows students to combine in the same time their two main concerns: having fun and working. Furthermore, despite constant agitation, there is no sustainable drop-out or major conflicts that disturb the smooth running of the lesson. The opportunity for students to have fun time offers them relaxation periods allowing them to remain involved in the realization of the motor and social skills, and not to withdraw for a long time. This management strategy also organizes the teacher's activity. This acceptance allows teachers to spend time for teaching and focusing on students' motor.

To conclude, this management strategy is based on accepting these furtive off-task games in order to prevent definitive disengagement. For the teacher, misbehaviors stay within the range of acceptable - or only slightly wrong - activity if they do not exceed 
certain limits. This management strategy based on the teacher's adaption to the nature of the detected disturbances constitutes a form of compromise in the class, between managing the students' misbehavior and their teaching. This typical form of compromise is controlled by the teachers - it allows them to intervene in the first place on the targeted motor and social abilities, thus meeting their educational objectives.

\section{Adapting management strategies with deviance boundaries}

The teachers' acceptance of the students' misbehavior is limited and needs to be permanently regulated following what happens in the classroom. The first of the teachers' management strategies is to 'close their eyes' on the off-task behaviors produced by such or such student - provided that these individual deviances do not spread through the class, other students, and do not threaten the collective work activity. A second management strategy comes from definite boundaries. Four deviance boundaries can lead the teacher to take action with authority to stop students' misbehaviors: (a) conflicts between students; (b) the threatening of the students' physical integrity; (c) the spreading of these deviances; and (d) the duration of misbehaviors.

First, teachers will intervene firmly when they detect the beginning of a violent conflict between students.

Teacher Y. talks during the self-confrontation interview $n^{\circ} 1$ : They continuously wind each other up ... continuously ... and it is a source of conflicts'. (... ) 'Upsetting your friends is a game which stops when the kid who is being upset loses patience at some point. You can see it, if the student who is being bothered is having as much fun as the one bothering him, then it's alright. But if I see them getting upset, then I will step in before it goes too far.

The four teacher studied have learnt how to detect the contentious potential of certain situations and can read the nature of the conflicts between students. To discriminate the conflicts' dangerous potential, they rely on precise indicators which they detect in the students' behavior. When students provoke each other for fun (have a laugh for a minute while doing their work), teachers observe their reactions - and especially the expression on their faces, the nature of their laughs and signs showing they become upset.

Second, teachers can also step in when the behavior of a student can be a prejudice to the physical integrity of other students.

For instance, during the third lesson of Teacher Y. One of the students found it funny to take the mat off while another was jumping. The teacher shouted the student's name from the other side of the gym and gathered all students to take control of the activity authoritatively.

The teachers studied are permanently and thoroughly keeping an eye on the students' physical safety during these gym activities. When they move about in the gym and stop near an activity, the first thing they do is to set the safety equipment back into place as soon as it has been moved the slightest by the students, whether voluntarily or not. They particularly focus on the activities involving a mini-trampoline for they know it is a piece of equipment offering a strong fun potential to the students.

Third, teachers can step in to stop deviances spreading to the whole class. The analysis shows that within the 26 lessons in difficult classes under watch poor behaviors spread very quickly among the students. In no time, a game between two students attracts other students who will deliberately take part in the game or start their own with other students. These deviances increase until they provoke the withdrawal from one or several activities. 
Teacher D. talks during the self-confrontation interview $n^{\circ} 1$ : Here it is a mess; I intervene directly ... there are students who leave their workshop. (...) The physical organization is a key element; it provides a working framework for students. Otherwise, it can go very fast and after you lose control. (...) There, you see both disruptive students returned to their workshop ... here we go (the class is back to work).

To control the spreading of misbehaviors, teachers must focus on the appropriation of space by the students. The way the students appropriate and organize themselves through space is an indicator providing information as for the working activity in class. A students' gathering will immediately draw the teachers' attention and they will understand it as a potential deviant behavior. They will also thoroughly keep an eye on the students' flow between workshops, as they know a student withdrawing from the expected task and leaving the spot will induce the transmission and spreading of disorder in the class.

Fourth, teachers will intervene firmly when they detect drop-outs lasting too long. Teachers are very careful about the amount of work produced by the students. The overall quantity of time during which the students stay involved in the task is another indicator for the teachers, telling them about the amount of work produced compared with the amount of effective misbehavior manifestations.

Teacher W. talks during the self-confrontation interview $\mathrm{n}^{\circ} 2$ : 'I saw them, I saw what they were doing, the sly devils, and I see that it does not degenerate, so I let them go. As long as it does not last very long.'

Teachers continuously monitored any deviations to ensure that they remained ephemeral. They thus monitored the progress of the class situation and intervened when students exceeded a boundary related to working time. When this boundary was crossed, the teachers intervened quickly. That is, they intervened when they found that the proportion of misbehavior exceeded the expected behaviors. The duration of these behaviors was a key indicator to guide their actions.

The management of student misbehavior by the teachers of this study had a typical character: these teachers exploited the deviant games to keep the students active, and they intervened only if the duration of off-task behaviors exceeded a boundary of acceptance. To conclude, controlled acceptance and the management of boundaries limits appear to be management strategies based on controlled typical compromises regulated by the teacher.

\section{Discussion and conclusion}

This case study investigates the relations between the students' motor and social involvement and the experienced PE teachers' task of managing the class, in a difficult educational context. The findings reveal that in spite of permanent agitation in the classroom, the students remained involved in the work with only short periods of disengagement and were appropriately committed both physically and socially. In order to put these difficult students at work and keep them focused during the whole lesson, the teacher uses specific management strategies based on a typical compromise of acceptance. We could not possibly generalize the findings of these case studies to all classes classified as 'difficult,' but they launch the debate on how teachers structure both their activities of instruction and maintaining order and about the management strategies for difficult classes while practicing gymnastics activities in workshop; and also on the differences and similarities between our findings with those of other research studying the fundamental characteristics of classroom misbehavior management in the context of schools under compensatory policies. Some of our 
results about students' misbehavior are congruent with research about incidents in classroom. These incidents are mostly not oral but physical deviances, moving about, or offtask behaviors (Hardy, Hardy, and Thorpe 1994; Turcotte et al. 2008).

The study presented here shows that the teachers managed to maintain student involvement in learning situations without lengthy drop-out periods thanks to (a) misbehavior acceptance as a compromise, (b) misbehavior acceptance boundaries, and (c) adaptation to the particular context of gym workshop.

First, the findings showed that the teachers' typical activity is organized around acceptance boundaries. This notion of acceptance goes along with the idea of a necessity for compromise in every educational activity (Flavier et al. 2002; McDermott 1977; Strauss 1992). What is particular to this class situation is the presence of a 'negotiated order' (Strauss 1992) or a 'working agreement' (McDermott 1977) based on permanent compromises between teachers and students so that both sides get involved in their task more easily. Compromises within the class allow the diverging interests of the teacher and their students to meet. This structure fulfills the first goal of the teacher which is to 'obtain and maintain collective collaboration within the class' (Doyle 1977, 47) or 'to reduce off-task behaviour and increase on-task behaviour' (Ward 2006, 9). More precisely we pointed out the teacher's management strategies related to his main concerns: avoid conflict and focus on student work. Teachers who took part in our study need to make compromises in order to avoid the emergence of open conflicts threatening the good progression of the lesson. This notion of compromise is similar to the concept of 'trading-off' in the ecological approach to classroom dynamics (Hastie and Pickwell 1996). Negotiation and 'trading-off' appear in our case studies - admittedly limited to four classes, four teachers, and 16 students - as strategies making class interactions possible by tacit, specific agreements (Flavier et al. 2002). The class is regarded as a complex and dynamic system, and teachers and students are necessarily brought to cooperate by 'trading-off,' something that is usual but not particularly widespread in difficult classes (Hastie and Pickwell 1996). These concessions seem to hit at the ethos of many teachers faced with questions about the moral acceptability of student misbehavior, but they become a vital necessity for success in 'doing' their work.

Second, our findings show that minor misbehaviors can only be tolerated up to acceptance boundaries beyond which there is no possible negotiation as for the teacher. This notion of acceptance boundaries looks like the notion of 'zone of acceptable responses' developed by Sanders and Graham (1995, 381-382), defined as a space of liberty granted by the teacher 'accepting some variation in responses from the children' linked with their persistent desire to play. These authors emphasize that the more difficult a class, the more teachers will need to accept off-task behaviors. This necessity for accepting some off-task games is particular to our study, based on especially difficult classes. Our study points out this specific boundary strategy as the systematic findings of the 26 lessons we focused on. Nevertheless, other researches show that despite these boundaries some students avoid the work (Doyle 1977; Tousignant and Siedentop 1983). Those students test the teacher's boundaries acting as 'competent bystanders' without misbehaving with a mock participation and counterfeit work (Tousignant and Siedentop 1983). In our study, teachers are attentive to the amount of work produced by the students; this acceptance boundary avoid this kind of mock participation.

Third, all our findings confirm the idea that the activity of managing the class varies following the students' characteristics - and especially their difficulties when it comes to working in groups or learning at school. Our study also demonstrates that other contextual aspects have an influence on the teacher-students interactions in class. Working in workshops during gym lessons implies that the students work in groups, often on their own, 
without continuous help from the teacher. It also means that teachers must divide their attention on all the different working sites spread among a vast gym (e.g. the workshops), and at the same time focus on one particular action to help one or several students. Their knowledge is seen through their ability to manage the students even at a distance, anticipate the possible conflicts, determine the order of importance of the deviances to adapt their actions, while keeping the students involved in the expected task, helping and correcting them to guide their learning. These findings relative to the specific context of workshops during gym lessons agree with the 'overlapping' practices employed by experienced teachers (Kounin 1970; Sabers, Cushing, and Berliner 1991).

As a conclusion our findings, even though limited to $26 \mathrm{PE}$ lessons, highlight the role of such acceptance and negotiation strategies from the teachers as a way to teach in particular classroom contexts with drop-out students. The teachers accepted misbehavior only insofar as it allowed these particularly difficult students to disengage briefly from the lesson before returning to constructive work. The learning activity in the particular settings of compensatory education has thus been questioned in this study, and the major finding is that it may consist of inseparable on-task and off-task behaviors. The idea is that if occasional off-task behaviors were not allowed, these difficult students would drop-out or enter in conflict with the teachers (Vors and Gal-Petitfaux Fourthcoming). The analysis reveals that the students go back to the expected task after short periods of disengagement by themselves. These self-regulated actions can be considered as a major indicator as for the success of the transactions in the class against disorderly actions (Bertone et al. 2002; Méard and Bertone 2009). These findings show that deviance and work should systematically be considered in a shared relationship of complementarity rather than opposition.

The great difficulty is to find the right proportions in this delicate balance. This study gives some indicators to judge if students' misbehaviors are viable. It also shows that experienced teachers are able to determine four deviance boundaries in classroom situation: the emergence of the conflicts between students, the threatening of the students' physical integrity, the spreading of these deviances, and the duration of misbehaviors.

These boundaries are based on the teacher perception of the conflicts between students, the threatening of the students' physical integrity, the spreading of these deviances, and the length of misbehaviors.

\section{Funding}

This research was sponsored by the Regional Council of Auvergne.

\section{Notes}

1. EPA.

2. A. Savary was the French Minister for Education between 1981 and 1984.

3. The majority of behaviours of the 16 students are changing every two successive occurrences.

\section{References}

Allen, J. D. 1986. “Classroom Management: Students' Perspectives, Goals, and Strategies.” American Educational Research Journal 23 (3): 437-459.

Armand, A., and B. Gille, eds. 2006. Rapport des inspections générales de l'éducation nationale. La contribution de l'éducation prioritaire à l'égalité des chances des élèves. Paris: MEN.

Beckers-Ledent, M., C. Delfosse, M. Cloes, and M. Piéron. 1995. "Problèmes rencontrés par des stagiaires dans l'enseignement des activités physiques et sportives. Analyse par la technique des incidents critiques." Revue de l'Education Physique 35 (1): 37-48. 
Bénabou, R., F. Kramarz, and C. Prost. 2009. "The French Zones d'éducation prioritaire: Much Ado about Nothing?" Economics of Education Review 28 (3): 345-356.

Berliner, D. C. 1979. "Tempus Educare." In Research on Teaching: Concepts, Findings, and Implications, edited by P. Peterson and H. Walberg, 120-135. Berkeley, CA: McCutchan.

Bertone, S., J. Méard, E. Flavier, J. P. Euzet, and M. Durand. 2002. "Undisciplined Actions and Teacher-Student Transactions During Two Physical Education Lessons." European Physical Education Review 8 (2): 99-117.

Bourbousson, J., G. Poizat, J. Saury, and C. Sève. 2011. "Cognition Collective: partage de préoccupations entre les joueurs d'une équipe de basket-ball au cours d'un match." Le travail humain 74 (1): 59-90.

Brunelle, J., J. P. Brunelle, J. Gagnon, R. Goyette, D. Martel, A. Marzouk, and C. Spallanzani. 1993. Système d'observation d'incidents disciplinaires (SOID). Québec: GRIAP, Département d'éducation physique, Université Laval.

Carlson, T. B., and P. A. Hastie. 1997. "The Student Social System Within Sport Education.” Journal of Teaching in Physical Education 16 (2): 176-195.

Chaliès, S., F. Bruno-Meard, J. Méard, and S. Bertone. 2010. "Training Preservice Teachers Rapidly: The Need to Articulate the Training Given by University Supervisors and Cooperating Teachers." Teaching and Teacher Education 26 (4): 767-774.

Chauveau, G. 2001. "La réussite scolaire dans les ZEP." Education et formations, no. 61: 147-151.

Demeuse, M., D. Frandji, D. Greger, and J. Y. Rochex, eds. 2008. Les politiques d'éducation prioritaire en Europe: conceptions, mises en oeuvre, débats. Lyon: INRP.

Doyle, W. 1977. "Paradigms for Research on Teacher Effectiveness." In Review of Research in Education, edited by L. S. Shulman, 163-198. Itasca, IL: F.E. Peacock.

Durand, M. 1996. L'enseignement en milieu scolaire. Paris: PUF.

Dyson, B. P., N. R. Linehan, and P. A. Hastie. 2010. "The Ecology of Cooperative Learning in Elementary Physical Education Classes." Journal of Teaching in Physical Education 29 (2): $113-130$.

Flavier, E., S. Bertone, D. Hauw, and M. Durand. 2002. "The Meaning and Organization of Physical Education Teachers' Actions During Conflict with Students." Journal of Teaching in Physical Education 22 (1): 20-38.

Gal-Petitfaux, N., and M. Cizeron. 2005. "Le travail par ateliers en Éducation Physique: activité de l'enseignant et activité des élèves." In Actes du Colloque International Recherche(s) et Formation "Former des enseignants-professionnels, savoirs et compétences», edited by IUFM des Pays de la Loire. Nantes: IUFM.

Gal-Petitfaux, N., C. Sève, M. Cizeron, and D. Adé. 2010. “Activité et expérience des acteurs en situation: les apports de l'anthropologie cognitive." In Sciences de l'intervention en EPS et en sport, edited by M. Musard, G. Carlier, and M. Loquet, 67-85. Paris: Éditions Revue EP.S.

Gal-Petitfaux, N., and O. Vors. 2008. "Socialiser et Transmettre des savoirs en classe d'Education physique: une synergie possible au prix d'une autorité pédagogique conciliante." Éducation et Francophonie 2 (XXXVI): 118-139.

Garn, A., R. W. Ware, and M. A. Solmon. 2011. "Student Engagement in High School Physical Education: Do Social Motivation Orientations Matter?" Journal of Teaching in Physical Education 1 (30): 84-98.

Guillou, J., and A. Durny. 2008. "Students' Situated Action in Physical Education: Analysis of Typical Concerns and Their Relations with Mobilized Knowledge in Table Tennis." Physical Education and Sport Pedagogy 13 (2): 153-169.

Hardy, C. A. 1996. "Student Misbehaviour and Teacher Response in Physical Education Lessons as Perceived by Students and Teachers." In Research on Teaching. Research on Teacher Education, edited by F. Carreiro da Costa, J. Diniz, L. Carvalho, and M. Onoffre, 95-102. Proceedings of the AIESEP international seminar, Lisbon. Lisbon: Universidade Technica de Lisboa.

Hardy, C. A. 1999. "Student Misbehaviours and Teachers' Responses in Physical Education Lessons." In Learning and Teaching in Physical Education, edited by C. A. Hardy and M. Mawer, 126-148. London: Falmer press.

Hardy, C. A., C. E. Hardy, and R. D. Thorpe. 1994. "Pupil Misbehaviour in Secondary Mixed-Sex Physical Education Lessons." British Journal of Physical Education Research, no. 15: 7-11.

Hastie, P. A. 1995. "An Ecology of a Secondary School Outdoor Adventure Camp." Journal of Teaching in Physical Education 15 (1): 79-97. 
Hastie, P. A. 2000. "An Ecological Analysis of a Sport Education Season." Journal of Teaching in Physical Education 19 (3): 355-373.

Hastie, P. A., and A. Pickwell. 1996. "Take Your Partners: A Description of a Student Social System in a Secondary School Dance Class." Journal of Teaching in Physical Education 15 (2): $171-187$.

Hastie, P. A., and D. Siedentop. 2006. “The Classroom Ecology Paradigm.” In Handbook of Physical Education, edited by D. Kirk, D. MacDonald, and M. O'Sullivan, 214-225. London: SAGE.

Hauw, D., G. Renault, and M. Durand. 2008. "How do Aerial Freestyler Skiers Land on their Feet? A Situated Analysis of Athletes' Activity Related to New Forms of Acrobatic Performance." Journal of Science and Medicine in Sport 11 (5): 481-486.

Hutchins, E. 1995. Cognition in the Wild. Cambridge: MIT press.

Kherroubi, M., and J. Y. Rochex. 2002. "Les ZEP: vingt ans de politiques et de recherches. Présentation." Revue française de pédagogie 2 (140): 5-7.

Kherroubi, M., and J. Y. Rochex. 2004. "La recherche en éducation et les ZEP en France. 2. Apprentissages et exercice professionnel en ZEP: résultats, analyses, interprétations." Revue française de pédagogie, no. 146: 115-190.

Kounin, J. S. 1970. Discipline and Group Management in Classrooms. New York: Holt Rinehardt and Winston.

Lave, J. 1988. Cognition in Practice: Mind, Mathematics, and Culture in Everyday Life. Cambridge: Cambridge University Press.

Machin, S., S. McNally, and C. Meghir. 2004. "Improving Pupil Performance in English Secondary Schools: Excellence in Cities." Journal of the European Economic Association 2 (2-3): 396-405.

McDermott, R. P. 1977. "Social Relations as Contexts for Learning in School." Harvard Educational Review 47 (2): 198-213.

Méard, J., and S. Bertone. 2009. "Analyse des transactions professeurs-élèves en éducation physique: étude de cas." STAPS, no. 83: 87-99.

Méard, J., S. Bertone, and E. Flavier. 2008. "How Second-Grade Students Internalize Rules During Teacher-Student Transactions: A Case Study." British Journal of Educational Psychology 78 (3): $395-410$.

Millet, M. 2004. Des élèves « en difficulté » aux élèves « difficiles »: l'exemple des collégiens de milieux populaires en « ruptures scolaires ». In Les jeunes en difficulté: leur place dans les politiques et dans la cité. Présenté à CNAM, Paris.

Monnier, N., and C. Amade-Escot. 2009. "L'activité didactique empêchée: outil d'intelligibilité de la pratique enseignante en milieu difficile." Revue française de pédagogie, no. 168: 59-73.

Pellerin, L. A. 2005. "Student Disengagement and the Socialization Styles of High Schools." Social Forces 84 (2): 1159-1179.

Piéron, M. 1982. Analyse de l'enseignement des activités physiques. Bruxelles: Ministère de l'Education Nationale et de la Culture française.

Piéron, M. 1993. Analyser l'enseignement pour mieux enseigner: éducation physique et sport. Paris: Revue EPS.

Piéron, M. 2005. "Research on Teaching Physical Activities and Sport: Paradigms and Selected Results." Italian Journal of Sport Sciences, no. 12: 4-17.

Piéron, M., and M. Emonts. 1988. "Analyse des problèmes de discipline dans les classes d'éducation physique.” Revue de l'éducation physique 28 (1): 33-40.

Ria, L., C. Sève, J. Saury, J. Theureau, and M. Durand. 2003. "Beginning Teachers' Situated Emotions: A Study of First Classroom Experiences." Journal of Education for Teaching 29 (3): $219-234$.

Rouve, M. E., and L. Ria. 2008. Analyse de l'activité professionnelle d'enseignants néo-titulaires en réseau « ambition réussite »: études de cas. Travail et formation en éducation, no. 1. Consulté à l'adresse. http://tfe.revues.org/index $565 . \mathrm{html}$

Rovegno, I. 2006. "Situated Perspectives on Learning." In Handbook of Physical Education, edited by D. Kirk, D. MacDonald, and M. O'Sullivan, 262-274. London: SAGE.

Sabers, D. S., K. S. Cushing, and D. C. Berliner. 1991. "Differences among Teachers in a Task Characterised by Simultaneity, Multidimensionality and Immediacy." American Educational Research Journal 28 (1): 63-88.

Sanders, S., and G. Graham. 1995. "Kindergarten Children's Initial Experiences in Physical Education: The Relentless Persistence for Play Clashes with the Zone of Acceptable responses." Journal of Teaching in Physical Education 14 (4): 372-383. 
Senac, R. 2000. "Zones d'Éducation Prioritaires: enjeux d'une politique." Revue européenne de migrations internationales 16 (3): 7-28.

Sève, C., J. Saury, S. Leblanc, and M. Durand. 2005. "Course-of-Action Theory in Table Tennis: A Qualitative Analysis of the Knowledge Used by Three Elite Players During Matches." European Review of Applied Psychology 55 (3): 145-155.

Siedentop, D. 1983. "Academic Learning Time: Reflections and Prospects." Journal of Teaching in Physical Education 2 (Issue Monograph): 3-7.

Siedentop, D., M. Tousignant, and M. Parker. 1982. "Academic Learning Time-Physical Education: 1982 Revision Coding Manual.” Unpublished manual, School of Health, Physical Education, and Recreation, The Ohio State University, Columbus, $\mathrm{OH}$.

Strauss, A. L. 1992. La trame de la négociation: sociologie qualitative et interactionnisme. Paris: L'Harmattan.

Suchman, L. A. 1987. Plans and Situated Actions. Cambridge: Cambridge University Press.

Suchman, L. A. 2007. Human-Machine Reconfigurations: Plans and Situated Actions. Cambridge: Cambridge University Press.

Theureau, J. 2003. "Course of Action Analysis and Course of Action Centred Design." In Handbook of Cognitive Task Design, edited by E. Hollnagel, 55-81. Mahwah, NJ: Lawrence Erlbaum Associates.

Theureau, J. 2006. Le cours d'action. Méthode développée. Toulouse: Octarès.

Theureau, J. 2009. Le cours d'action. Méthode réfléchie. Toulouse: Octarès.

Theureau, J. 2010. "Les entretiens d'autoconfrontation et de remise en situation par les traces matérielles et le programme de recherche «cours d'action»." Revue d'anthropologie des connaissances 4 (2): $287-322$.

Theureau, J., and G. Filippi. 2000. "Analysing Cooperative Work in an Urban Traffic Control Room for the Design of a Coordination Support System." In Workplace Studies: Recovering Work Practice and Informing System Design, edited by P. Luff, J. Hindmarsh, and C. Heath, 68-91. Cambridge: Cambridge Univeristy Press.

Tousignant, M., and D. Siedentop. 1983. "A Qualitative Analysis of Task Structures in Required Secondary Physical Education Classes." Journal of Teaching in Physical Education 3 (1): 47-57.

Turcotte, S., J. F. Desbiens, C. Spallanzani, M. Roy, J. P. Brunelle, and J. S. Tourigny. 2008. "Portrait des comportements perturbateurs adoptés par des élèves du niveau primaire en éducation physique et à la santé." eJRIEPS 2 (13): 57-77.

Van der Mars, H. 2006. "Time and Learning in Physical Education." In Handbook of Physical Education, edited by D. Kirk, D. MacDonald, and M. O'Sullivan, 191-213. London: SAGE.

Veyrunes, P., N. Gal-Petitfaux, and M. Durand. 2009. "Configurations of Activity: From the Coupling of Individual Actions to the Emergence of Collective Activity. A Study of Mathematics Teaching Situation in Primary School." Research Papers in Education 24 (1): 95-113.

Vors, O., N. Gal-Petitfaux, and M. Cizeron. 2010. "Signification des comportements à connotation violente et gestion des interactions dans une classe RAR." International Journal on Violence and School, no. 11: 2-32.

Vors, O., and N. Gal-Petitfaux. Forthcoming. Formes d'expériences sensorielles structurant les stratégies d'intervention en classe difficile. Recherches et Éducations.

Ward, P. 2006. "The Philosophy, Science and Application of Behavior Analysis in Physical Education." In Handbook of Physical Education, edited by D. Kirk, D. MacDonald, and M. O'Sullivan, 3-21. London: SAGE.

Ward, P., and M. O'Sullivan. 2006. "The Contexts of Urban Settings." Journal of Teaching in Physical Education 25 (4): 248-362. 